\title{
TENSILE PROPERTIES AND MICROSTRUCTURE OF DIRECT METAL LASER-SINTERED TI6AL4V (ELI)
} ALLOY

\author{
M.G. Moletsane ${ }^{1 * \#}$, P. Krakhmalev², N. Kazantseva ${ }^{3}$, A. Du Plessis ${ }^{4}$, I. Yadroitsava ${ }^{1} \&$ \\ I. Yadroitsev ${ }^{1}$
}

\section{ARTICLE INFO}

\section{Article details}

Presented at the $17^{\text {th }}$ annual

international conference of the Rapid

Product Development Association of

South Africa (RAPDASA), held from 2-4

November 2016 in Vanderbijlpark, South Africa

Available online $\quad 11$ Nov 2016

\section{Contact details}

Corresponding author

mmoletsane@cut.ac.za

Author affiliations

1 Department of Mechanical and Mechatronic Engineering, Central University of Technology, Free State, South Africa

2 Karlstad University, Department of Engineering and Physics, Sweden

3 Institute of Metal Physics, Urals Branch of the Academy of Sciences, Ekaterinburg, Russia

4 University of Stellenbosch, CT Scanner Facility, Stellenbosch, South Africa

\# The author was enrolled for an $M$ Eng degree in the Department of Department of Mechanical and Mechatronic Engineering, Central University of Technology, Free State, South Africa.

\section{DO}

http://dx.doi.org/10.7166/27-3-1667

\section{ABSTRACT}

Direct metal laser sintering (DMLS) is an additive manufacturing technology used to melt metal powder by high laser power to produce customised parts, light-weight structures, or other complex objects. During DMLS, powder is melted and solidified track-by-track and layer-by-layer; thus, building direction can influence the mechanical properties of DMLS parts. The mechanical properties and microstructure of material produced by DMLS can depend on the powder properties, process parameters, scanning strategy, and building geometry. In this study, the microstructure, tensile properties, and porosity of DMLS Ti6Al4V (ELI) horizontal samples were analysed. Defect analysis by CT scans in pre-strained samples was used to detect the crack formation mechanism during tensile testing of as-built and heat-treated samples. The mechanical properties of the samples before and after stress relieving are discussed.

\section{OPSOMMING}

Direkte lasermetaalsintering is ' $n$ toevoegingsvervaardigingtegniek wat gebruik word om metaalpoeier met 'n hoë drywing laser te smelt. So word doelgemaakte onderdele, ligte strukture of ander ingewikkelde voorwerpe geproduseer. Metaal poeier word gesmelt en gestol op 'n baan-vir-baan, laag-vir-laag wyse. Die bou rigting kan dus die meganiese eienskappe van die onderdeel beïnvloed. Die meganiese eienskappe en mikrostruktuur van materiaal wat met direkte lasermetaalsintering geproduseer word hang onder andere van die poeier eienskappe, die proses parameters, skandeer strategie en bou geometrie af. Die mikrostruktuur, trekeienskappe en poreusheid van direkte lasermetaalgesinterde Ti6Al4V horisontale monsters is analiseer. ' $n$ Defekanalise met behulp van CT-skanderings in die vooraf vervormde monsters is gebruik om die kraakvormingsmeganisme tydens die trektoetse te bepaal. Onbehandelde en hittebehandelde monsters is getoets. Die meganiese eienskappe van die monsters word in detail bespreek.

\section{INTRODUCTION}

Direct metal laser sintering (DMLS) can significantly influence the performance of implants from biocompatible alloys because this additive manufacturing technology is able to manufacture customised shape parts, light-weight structures, or other complex objects from metal powder by laser. The DMLS object consists of many tracks and layers having metallurgical contact with each other, and its microstructure is a result of multiple rapid heating-melting-solidification cycles. The complex microstructure of DMLS alloys, which is different from cast/wrought material, is a result of the different phases in the material, the solidification texture caused by the nature of manufacturing (track-by-track and layer-by-layer), residual stresses arising at high thermal gradients and thermocycling, and the high probability of pore formation in the case of non-stable process parameters. Mechanical properties depend not only on the material, but also on the laser's process- 
parameters, the building and scanning strategies, the powder layer's thickness, and the protective atmosphere.

Titanium and its alloys are widely used as biomaterial because they have low weight and high strength, good fracture toughness, and high corrosion resistance. The protective and stable oxides on the titanium surface are able to provide osseointegration, which is favourable for the structural and functional connection between bone and implant [1].

The mechanical properties of two-phase titanium alloys, like Ti6Al4V, strongly depend on the number, distribution, and morphology of the phases [2, 3]. Ti6Al4V with lamellar structures has high strength with some decrease in ductility, and demonstrates good fracture toughness. Refinement of the microstructure results in a higher yield stress.

Table 1 shows the mechanical properties of the DMLS Ti6Al4V and Ti6Al4V (ELI) samples that were built horizontally. All the indicated sources showed that the as-built samples had a fine $\alpha$ ' martensitic microstructure. High cooling rates at DMLS result in the formation of the acicular/lamellar $\alpha^{\prime}$ hexagonal martensitic phase in Ti6Al4V. At cross-sections along the building direction, columnar structures are clearly visible, whilst in the transverse direction, bundles of columnar grains can be seen. A martensitic $\alpha$ ' microstructure is less ductile than the globular microstructure formed during conventional processing [4]. Strongly-textured structures can lead to significant anisotropic mechanical properties, causing different mechanical responses to external loading along different sample orientations [5]. Even for specimens built in the same direction, a discrepancy in the data for the mechanical properties of DMLS Ti6Al4V is 1.28 times for ultimate tensile strength (UTS), 1,407 versus $1,095 \mathrm{MPa}, 1.35$ times for yield strength (YS), 990 versus $1,333 \mathrm{MPa}$, and the difference is 4.25 times $(2-8.5 \%)$ for elongation (Table 1$)$. The coefficient of variation $(\mathrm{CV})$, which represents the ratio of the standard deviation to the average, was up to 48 per cent for elongation at break.

Table 1: Tensile properties of as-built and annealed DMLS horizontal Ti6Al4V samples

\begin{tabular}{|c|c|c|c|c|c|c|c|}
\hline $\begin{array}{l}\text { Machine/Process- } \\
\text { parameters (if indicated) }\end{array}$ & $\begin{array}{l}\text { UTS, } \\
\text { MPa }\end{array}$ & $\mathrm{YS}, \mathrm{MPa}$ & \begin{tabular}{|l} 
Elastic \\
modulus, \\
$\mathrm{GPa}$
\end{tabular} & $\begin{array}{l}\text { Elongation } \\
\text { at break, \% }\end{array}$ & Density & $\begin{array}{l}\text { Micro- } \\
\text { structure }\end{array}$ & Source \\
\hline \multicolumn{8}{|c|}{ Ti6Al4V alloy } \\
\hline $\begin{array}{l}\text { Experimental machine } \\
\text { built at ILT }\end{array}$ & $1140 \pm 10$ & $1040 \pm 10$ & & $8.2 \pm 0.3$ & \multirow[t]{2}{*}{$\begin{array}{l}99.7 \\
\pm 0.1\end{array}$} & \multirow[t]{2}{*}{ acicular $\alpha^{\prime}$} & {$[10]$} \\
\hline $\begin{array}{l}\text { EOSINT M270 } \\
\text { Laser power, } 195 \mathrm{~W} \\
\text { Scanning speed, } \\
0.225 \mathrm{~m} / \mathrm{s}\end{array}$ & $1095 \pm 10$ & $990 \pm 5$ & $110 \pm 5$ & $8.1 \pm 0.3$ & & & {$[10]$} \\
\hline EOSINT M270 & 1248 & 1043 & 112 & 8.5 & & & {$[11]$} \\
\hline EOSINT M270 & $1269 \pm 9$ & $1195 \pm 19$ & & $5 \pm 0.5$ & & $\begin{array}{l}\alpha^{\prime} \text { martensitic } \\
\text { laths } \\
\end{array}$ & {$[12]$} \\
\hline EOSINT M270 & 1407 & 1333 & & 4.54 & & $\alpha^{\prime}$ plates & {$[13]$} \\
\hline $\begin{array}{l}\text { EOSINT M280 } \\
\text { Standard process } \\
\text { parameters for } 30 \mu \mathrm{m} \\
\text { powder layer thickness }\end{array}$ & $1155 \pm 20$ & & & $4.1 \pm 2$ & $\begin{array}{l}99.79 \\
\pm 0.2\end{array}$ & $\begin{array}{l}\text { fine acicular a' } \\
\text { martensite }\end{array}$ & \multirow[t]{2}{*}[8]{} \\
\hline $\begin{array}{l}\text { After stress-relief heat } \\
\text { treatment }\end{array}$ & $1230 \pm 20$ & & & $7.0 \pm 2$ & & & \\
\hline $\begin{array}{l}\text { MTT SLM } 250 \\
\text { Laser power, } 175 \mathrm{~W} \text {, } \\
2 \mathrm{~mm} \text { FOD } \\
\text { Scanning speed, } 0.71 \mathrm{~m} / \mathrm{s} \\
\text { Layer thickness, } 30 \mu \mathrm{m} \\
\text { Hatch distance, } 120 \mu \mathrm{m}\end{array}$ & $1321 \pm 6$ & $1166 \pm 6$ & 112 & $2 \pm 0.7$ & $>99.5$ & $\alpha^{\prime}$, no $\beta$-phase & \multirow[t]{2}{*}{ [9] } \\
\hline Annealed $640^{\circ} \mathrm{C}$ for $4 \mathrm{hrs}$ & $1225 \pm 4$ & $1104+8$ & & $7.4 \pm 1.6$ & & $\begin{array}{l}\text { no significant } \\
\text { micro- } \\
\text { structural } \\
\text { change } \\
\end{array}$ & \\
\hline
\end{tabular}




\begin{tabular}{|c|c|c|c|c|c|c|c|}
\hline \multicolumn{8}{|c|}{$\begin{array}{c}\text { Ti6Al4V (ELI) } \\
\end{array}$} \\
\hline $\begin{array}{l}\text { Laser power, } 250 \mathrm{~W} \\
\text { Spot size, } 52 \mu \mathrm{m} \\
\text { Scanning speed, } 1.6 \mathrm{~m} / \mathrm{s} \\
\text { Layer thickness, } 30 \mu \mathrm{m} \\
\text { Hatch distance, } 60 \mu \mathrm{m}\end{array}$ & $1267 \pm 5$ & $1110 \pm 9$ & $109.2 \pm 3.1$ & $7.28 \pm 1.12$ & $\begin{array}{l}\text { fully } \\
\text { dense }\end{array}$ & $\begin{array}{l}\text { acicular } \alpha^{\prime} \\
\text { martensitic }\end{array}$ & [6] \\
\hline $\begin{array}{l}\text { Heat treatment } 3 \mathrm{~h} \text { at } \\
705^{\circ} \mathrm{C} \text {, air cooling }\end{array}$ & $1082 \pm 34$ & $1026 \pm 35$ & $114.6 \pm 2.2$ & $\begin{array}{l}9.04 \pm \\
2.03 \\
\end{array}$ & & & \\
\hline $\begin{array}{l}\text { Trumpf LF250 } \\
\text { Laser power, } 200 \mathrm{~W} \\
\text { Spot size, } 220 \mu \mathrm{m} \\
\text { Scanning speed, } 0.5 \mathrm{~m} / \mathrm{s} \\
\text { Layer thickness, } 30 \mu \mathrm{m} \\
\text { Hatch distance, } 200 \mu \mathrm{m} \\
\text { Preheating } 500^{\circ} \mathrm{C}\end{array}$ & $1206 \pm 8$ & $1137 \pm 20$ & $105 \pm 5$ & $7.6 \pm 2$ & & $\begin{array}{l}\text { acicular } \alpha^{\prime} \\
\text { martensitic }\end{array}$ & [7] \\
\hline $\begin{array}{l}\text { Annealing at } 730^{\circ} \mathrm{C} \text { for } 2 \\
\text { hrs, air cooling }\end{array}$ & $1046 \pm 6$ & $965 \pm 16$ & $101 \pm 4$ & $9.5 \pm 1$ & & $\begin{array}{l}\text { needle } \alpha \text { ' phase } \\
\text { embedded in } \alpha+\beta\end{array}$ & \\
\hline $\begin{array}{l}\text { Annealed wrought Ti6Al4V } \\
\text { (ELI) ASTM F136-13 }\end{array}$ & Min 825 & Min 760 & & Min 8 & Area 1 & uction: Min $14-15 \%$ & \\
\hline
\end{tabular}

According to the standard specifications for wrought Ti6Al4V (ELI) and cast Ti6AlV alloys for surgical implant applications (ASTM F136-13 and ASTM F1108-14), the elongation of the material should be at least 8 per cent (Table 1). The content of interstitials has a substantial influence on the mechanical properties of Ti6Al4V. As indicated by Boyer et al. [3] and Donachie [2], an oxygen content higher than $0.2 \mathrm{wt}$ \% leads to a higher strength and a lower ductility in the Ti6Al4V alloy. A decrease in oxygen and nitrogen content improves the ductility, fracture toughness, stress-corrosion resistance, and resistance against crack growth. As published in the literature, the UTS for DMLS Ti6Al4V (ELI) horizontal samples varied from 1,206 to 1,267 MPa, with an average YS from 1,110 to $1,137 \mathrm{MPa}$, and a Young's modulus of $105-109 \mathrm{GPa}$ [6-7]. After annealing at $730^{\circ} \mathrm{C}$ for two hours and air cooling, needle $\alpha$ ' phase embedded in $\alpha+\beta$ phases was found [7]. No significant microstructural changes were identified after stress-relieving heat treatment at temperatures lower than $650{ }^{\circ} \mathrm{C}$. UTS increased by 6 per cent [8] or decreased by 8 per cent [9] for Ti6Al4V alloy, and decreased by 15-17 per cent for Ti6Al4V ELI alloy [6-7]. After heat treatment, elongation was increased 3.7 times for Ti6Al4V and 1.25 times for Ti6Al4V (ELI).

Thus the difference in the mechanical properties of the samples and a wide scatter of the data raises an urgent issue about the repeatability of the mechanical properties of TI6Al4V alloy, and the impact of porosity and the chemical composition on the mechanical properties of the DMLS samples. The purpose of the study is to investigate the microstructure and mechanical properties in as-built and stress-relieved conditions, and to compare them with the international standards for biomedical applications. In-situ development of porosity at tension of Ti6Al4V (ELI) samples was used to determine fracture mechanisms for as-built and heat-treated specimens.

\section{MATERIALS AND METHODS}

\subsection{Powder and manufacturing of the DMLS samples}

The chemical composition of the employed spherical argon-atomised Ti6Al4V (ELI) $(-45 \mu \mathrm{m})$ powder from TLS Technik was as follows in wt.\%: Ti (bal.), Al (6.44), V (3.99), O $(0.12), \mathrm{N}(<0.002), \mathrm{H}(0.001)$, Fe (0.19), $C(0.007)$, and $Y(<0.001)$. The chemical composition corresponds to the ASTM standard for $\mathrm{Ti}$ grade 23 . The $10^{\text {th }}, 50^{\text {th }}$, and $90^{\text {th }}$ percentiles of the equivalent diameter (weighted by volume) of the powder particles were $d_{10}=11.2 \mu \mathrm{m}, d_{50}=20.6 \mu \mathrm{m}$, and $d_{90}=31.8 \mu \mathrm{m}$ respectively. The Ti6Al4V samples were produced by the EOSINT M280 system. A back-and-forth (zig-zag) scanning by strips with a hatch distance of $100 \mu \mathrm{m}$ was applied when manufacturing the blocks. The blocks were built without supports, directly on the substrate. The substrate and powder materials were similar in chemical composition. Argon was used as the protective atmosphere; the oxygen level in the chamber was 0.07-0.12 per cent. A first series of as-built rectangular bars were cut off from the substrate; a second series of specimens remained on the substrate and were heat-treated in argon atmosphere at $650^{\circ} \mathrm{C}$ (three hours) for stress relieving. 


\subsection{Microstructural analysis}

Scanning electron microscopy (SEM) was carried out with the LEO 1350 FEG-SEM operated at $20 \mathrm{kV}$, and the NeoScope JCM 5000. Cross-sections of the samples were subjected to grinding with $320 \mathrm{SiC}$ paper, then polishing by $9 \mu \mathrm{m}$ diamond suspension and with $0.05 \mu \mathrm{m}$ Silica. Cross-sections of the samples were etched in Kroll's reagent. Transmission electron microscopy (TEM) was done with JEOL JEM 2100, equipped with a LaB6 cathode and a digital camera Gatan SC1000 Orius, and JEM-200CX. Specimens for TEM were electro-chemically prepared.

\subsection{Tensile tests}

Round metal specimens with threaded ends were machined from DMLS rectangular bars $10 \mathrm{~mm} \times$ $10 \mathrm{~mm} \times 60 \mathrm{~mm}$ in size according to the geometry recommended by ASTM E8M standard (gauge length four times the diameter). Tensile tests were performed with an Instron 1342 servo-hydraulic testing machine with a clip-on extensometer of $12.5 \mathrm{~mm}$ and under a constant strain rate of $1.5 \mathrm{~mm} / \mathrm{min}$.

\subsection{X-ray micro-computed tomography}

The samples were subjected to X-ray micro-computed tomography (MicroCT) [14]. MicroCT scans were done with a General Electric Phoenix V|Tome|X L240 system at $160 \mathrm{kV}$ and $200 \mu \mathrm{A}$, including beam filtering of $0.5 \mathrm{~mm}$ copper; the resolution was $10 \mu \mathrm{m}$. CT image reconstruction was done with system-supplied software that included beam hardening correction. All analyses were done with Volume Graphics VGStudioMax 2.2, including the defect analysis module and the nominal/actual comparison module. 3D image processing was done using morphological image operations to select the sample sub-surface by four voxels, in order to eliminate any edge noise effects. Therefore any voids touching the sample edge would not be included in the analysis up to four voxels $(40 \mu \mathrm{m})$. Defect analysis is run with a minimum pore detection limit of eight voxels, a maximum pore size of $10 \mathrm{~mm}$, and a probability of $1-3$. MicroCT was used to visualise and quantify the necking effect on the tensile samples.

\subsection{Design of the experiment with pre-strained samples}

As-built ( $A B)$ and stress-relieved (SR) horizontal samples were tested to investigate such strength characteristics as YS, UTS, Young's modulus, elongation, and area reduction. Some stress-relieved specimens were pre-strained, and then porosity was investigated using the CT scanner (Figure 1).

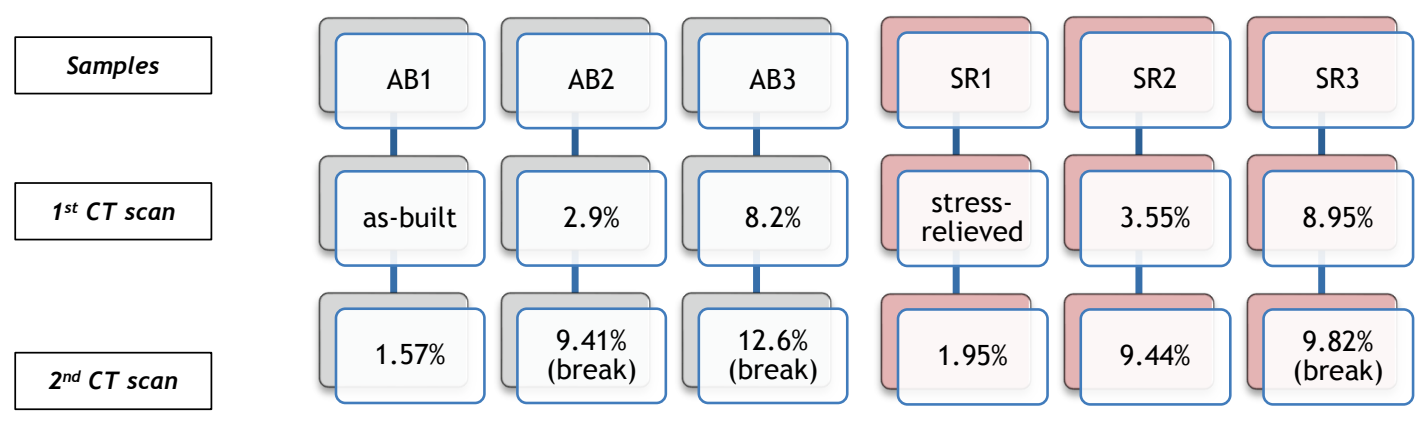

As-built samples

Stress-relieved samples

Figure 1: Design of the experiments with the pre-strained tensile samples; resulting elongation is indicated

\section{RESULTS AND DISCUSSION}

\subsection{Microstructure}

During DMLS, powder is melted and solidified track-by-track and layer-by-layer; thus building direction influences the mechanical properties of DMLS parts. Since high thermal gradients and thermal cycling lead to high residual stress, twinning was observed by TEM in the as-built material. The microstructure of the as-built Ti6Al4V alloy typically consists of $a^{\prime}$ martensite. Solidification of 
molten alloy starts with the formation of the primary cubic beta phase. It has been shown that the as-solidified beta phase showed pronounced texture $<100>$ [15]. At rapid cooling below Ms temperature, beta is transformed to $a^{\prime}$ martensite, which also has a crystallographic orientation relationship with the parental beta.

Figure 2 illustrates an EBSD orientation map of the as-built Ti6Al4V specimens. Inverse pole figure (IPS) components were used to colour the (a), (b), and (c) maps in Figure 2 so that the red, blue, or green colour corresponds to gains with $\langle 0001\rangle,\langle 10-10\rangle$, or $\langle 1-1-20\rangle$ directions parallel to the axes $\mathrm{X}, \mathrm{Y}$, or $\mathrm{Z}$ respectively. Directions $\mathrm{X}$ and $\mathrm{Y}$ are parallel to the laser scanning directions and form a horizontal plane, while direction $\mathrm{Z}$ is the building direction. It is seen that, although the grain boundaries of the primary beta phase were easily distinguished, no obvious textures were observed in the $a^{\prime}$ martensitic phase. Image analysis showed that the lamella thickness was in the range of 1.9-2.3 $\mu \mathrm{m}$. Additionally, no beta phase was observed in the as-built alloy, by neither TEM nor EBSD methods. The results of the EBSD analysis carried out in the present investigations agreed well with the weak texture of $a^{\prime}$ observed by Simonelli et al. [16], who explained weak texture observed in $a^{\prime}$ by a high number of variants that $a^{\prime}$ could precipitate within each prior beta grain.
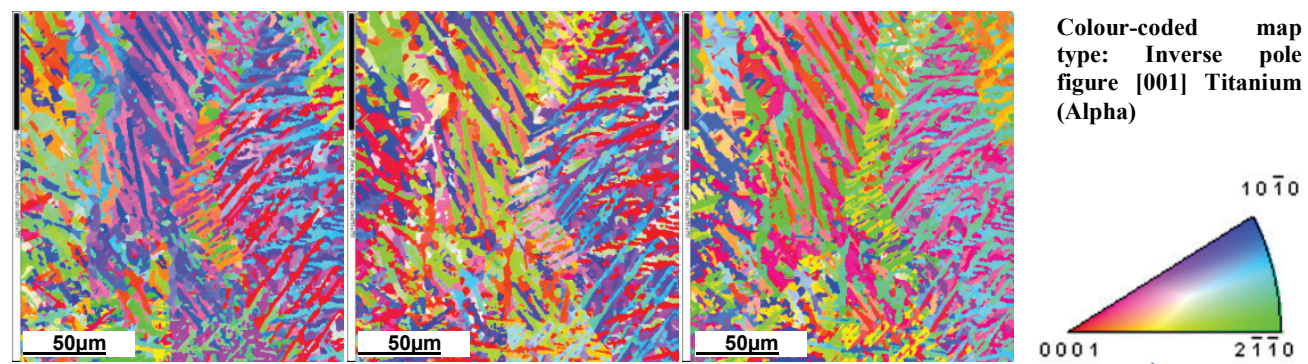

Figure 2: IPF EBSD orientation map, $\langle 0001\rangle,\langle 10-10\rangle$, or $\langle 2-1-10\rangle$ directions parallel to (a) - X direction, (b) - Y direction, and (c) - Z (building) direction

Heat treatment in the $a+B$ region commonly leads to a decomposition of the martensite. Nevertheless, stress relief of Ti6Al4V at $650^{\circ} \mathrm{C}$ for three hours only slightly influenced the microstructure. Although some changes in the morphology hexagonal phase were observed and a number of indexed by EBSD high-angle boundaries was detected, no remarkable increase in an average thickness of lamella was observed (see Figures 3a-c). Analysis of the results of the transmission electron microscopy of the Ti6Al4V specimens in stress-relieved conditions revealed the presence of very small globular grains of the alpha phase formed after the heat treatment. It indicates that new grains nucleation and growth processes had already started in the microstructure after three hours at $650^{\circ} \mathrm{C}$. Nevertheless, only a few globular grains were observed in the TEM in this investigation, and none of them exceeded $500 \mathrm{~nm}$ in size. However, TEM, EBSD, and XRD carried out in the present research did not reveal the formation of detectable amounts of beta phase in the stress-relieved specimens.

The experimental observations differed from the results presented by various authors $[6,7,17,18]$, where the decomposition of martensite and formation of the beta phase started after stress-relief treatment at $730-800^{\circ} \mathrm{C}$ for $1-2 \mathrm{hrs}$. A reason for the deviation could be that the stress-relief heat treatment was done at temperatures remarkably higher than those in the present work. It also agrees well with the DCS analysis carried out by Sallica-Leva [17], which has shown that $a^{\prime} \rightarrow a+B$ decomposition takes place in a temperature interval of $760-850^{\circ} \mathrm{C}$, while the stress relief occurred between 440 and $590^{\circ} \mathrm{C}$. Nevertheless, Sallica-Leva [17] has also shown the presence of the beta phase already after treatment for $2 \mathrm{hrs}$ at $650^{\circ} \mathrm{C}$. This contradiction could be explained by taking into account the thermal history of the material manufactured by SLM/DMLS. It has been shown that, when depending on manufacturing regimes, the final structure is subjected to different conditions of in-situ cycling reheating, which influences the microstructure of the material $[5,19]$. 

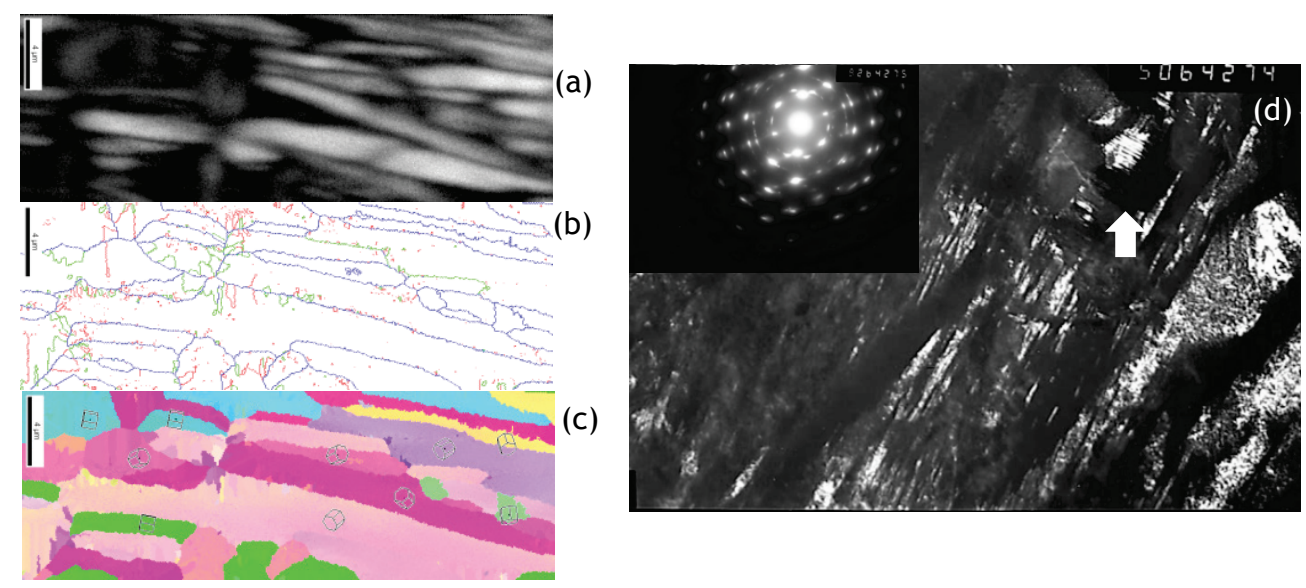

Figure 3: (a) SEM image, (b) grain boundary reconstruction, and (c) IPF EBSD orientation map of Ti6Al4V stress-relieved at $650^{\circ} \mathrm{C}$ for three hours; (d) the dark-field TEM image of stressrelieved Ti6Al4V made in (110) hcp reflex

\subsection{Mechanical properties}

In the present investigations, $0.19 \mathrm{wt} . \%$ oxygen and $0.058 \mathrm{wt} . \%$ nitrogen were measured in the DMLS specimens, which is slightly higher than the nominal content. The experimentally-observed mechanical properties were similar to the ones summarised in Table 1. The tensile stress-strain curves of the as-built and stress-relieved Ti6Al4V are shown in Figure 4, and are summarised in Table 2. It was found that the as-built and stress-relieved samples had higher YS and UTS than annealed wrought Ti6Al4V (ELI) (in Table 1). As can be seen from Figure 4, the differences in the mechanical properties of the horizontal specimens in each series were small, and the coefficients of variation were very low (Table 2 ).

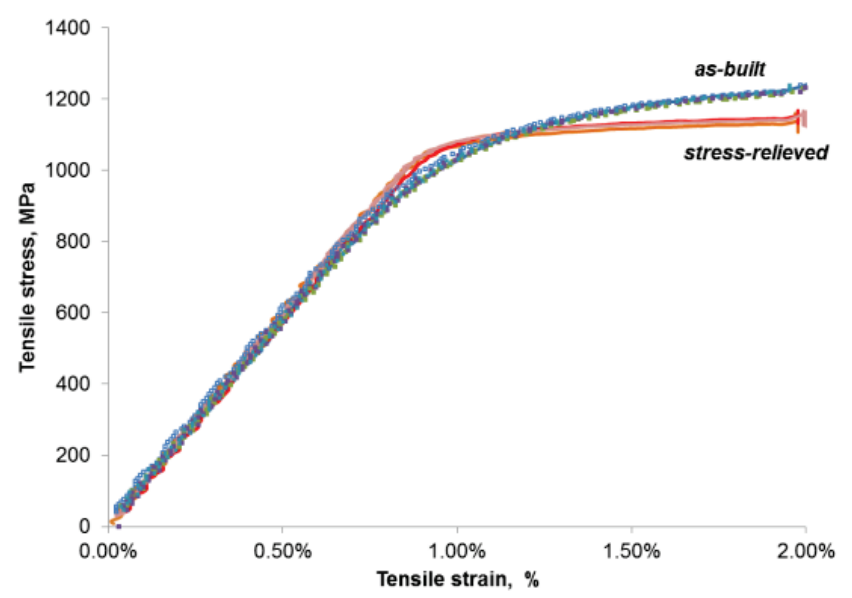

Figure 4: Stress-strain diagram of Ti6Al4V (ELI) samples before and after stress-relieving heat treatment

Vickers microhardness at $300 \mathrm{~g}$ load was measured on the as-built and stress-relieved specimens. The microhardness for different cross-sections was similar, and the values did not show any statistically significant difference $(t$-test, $p<0.001)$ with reference to the building direction. The average value was $389 \pm 14.8 \mathrm{HV}_{300}$ for the as-built samples, and the microhardness was slightly lower $\left(374 \pm 17 \mathrm{HV}_{300}\right)$ for the stress-relieved samples. The stress-relieving heat treatment led to an increase in the area reduction from 25.6 per cent (AB samples) to 29.3 per cent (SR samples). The elongation was 9.4 per cent for the as-built Ti6Al4V samples, and increased to 10.9 per cent after the stress relief. These ductility properties satisfied the standards for medical applications. 
Table 2: Tensile properties of horizontal DMLS Ti6Al4V (ELI) samples

\begin{tabular}{|c|c|c|c|c|c|}
\hline Specimens & $\begin{array}{c}\text { YTS (Offset } \\
\mathbf{0 . 2} \% \text { ), MPa }\end{array}$ & $\begin{array}{c}\text { Modulus (Chord 200 MPa } \\
-800 \mathrm{MPa} \text { ), GPa }\end{array}$ & $\begin{array}{c}\text { UTS, } \\
\mathrm{MPa}\end{array}$ & $\begin{array}{c}\text { Elongation, \% } \\
\text { 4D }\end{array}$ & $\begin{array}{c}\text { Area } \\
\text { reduction, \% }\end{array}$ \\
\hline $\begin{array}{c}\text { As-built } \\
\text { average } \pm \text { S.D. }\end{array}$ & $1098 \pm 2$ & $112 \pm 2$ & $1265 \pm 5$ & $9.4 \pm 0.46$ & $25.6 \pm 2.41$ \\
\hline CV & 0.002 & 0.02 & 0.004 & 0.05 & 0.09 \\
\hline $\begin{array}{c}\text { Stress- } \\
\text { relieved } \\
\text { average } \pm \text { S.D }\end{array}$ & $1098 \pm 5$ & $117 \pm 2^{*}$ & $1170 \pm 6^{*}$ & $10.9 \pm 0.8^{*}$ & $29.3 \pm 0.78^{*}$ \\
\hline CV & 0.005 & 0.02 & 0.005 & 0.07 & 0.03 \\
\hline
\end{tabular}

* Significant differences ( $t$-test, $\mathrm{p}<0.05)$

\subsection{Analysis of fracture surfaces}

After the tensile tests, the fracture surfaces in the as-built and stress-relieved samples look like a 'cup and cone', which is characteristic for ductile types of the fractures (Figures $5 a \& b$ ). The central area was clearly distinguished from the shear lips on the periphery. The fractured surface in the central zone was irregular, not horizontal, with the formation of dimples (Figures $5 c \& d$ ). Although the dimple rupture dominated, quasi-cleavage facets features of a brittle kind were observed (Figures $5 e \& f$ ).

High-magnification analysis showed that martensite needles are often visible on the quasi-cleavage surfaces. Therefore it is possible to confirm that these regions are formed when the crack propagates along a martensite colony. When the crack reaches a primary beta grain boundary or a fusion boundary, the growth direction is changed. The interface, therefore, acts as a crack deflector, preventing quick failure. This conclusion is in agreement with the results presented by Wen et al. [20]. Since the mechanisms of ductile fracture and the formation of a cup-and-cone shape in the necking region are usually associated with pore coalescence, a defect analysis by CT scans in the pre-strained samples was used to detect the crack formation mechanism.

\subsection{Defect analysis and crack formation mechanisms}

The process of defect analysis of the samples with a low level of porosity and small pores is a complex task in CT scans because small pores and the noise signal can be overlapped [21]. Some pores can be missed due to contrast variations between the scans, and due to the metal type and size of the pores relative to the scan resolution. After DMLS at optimal process parameters, the Ti6Al4V (ELI) as-built and stress-relieved samples had low levels of porosity. In the as-built sample, 34 pores in total were found, which totalled 0.0022 per cent porosity. In the stress-relieved specimen, 40 pores were indicated and porosity was 0.0018 per cent. On the whole, pores were coarser, and a maximum pore size of $132 \mu \mathrm{m}$ was measured in the as-built sample (Figure 6). An analysis of the pore geometry showed that most estimated pores had an elongated shape (Figure 6b); the sphericity factor for the as-built sample was $0.62 \pm 0.03$ and $0.71 \pm 0.06$ for the stress-relieved ones (for the ideal sphere, the sphericity factor is equal to 1.0). The biggest pores were elongated perpendicular to the building direction and can apparently be classified as interlayer pores.

To investigate the evolution of porosity, the development of pore size and morphology, and the influence of these parameters on mechanical behaviour, as-built and stress-relieved specimens were pre-strained to 1.57-9.44 per cent (Figure 1). The morphology of the pores and their size were substantially changed after pre-strain (Figures 6-8). In the pre-strained samples, pores look like an agglomerate of several pores. Some pores were interconnected with quite thin channels, possibly cracks (Figures $7 \mathrm{a}, \mathrm{c}$ ). Pore coarsening has been observed in both as-built and stress-relieved specimens. Thus the AB3 sample, pre-strained up to 8.2 per cent, had the biggest pore size of $236 \mu \mathrm{m}$. The maximum pore sizes in the stress-relieved specimens deformed at 8.95-9.44 per cent, but still had integrity, and were 100-160 $\mu \mathrm{m}$ (Figures 7 \& 8).

Generally, this behaviour is described by the cumulative curves presented in Figure 8. An analysis of the cumulative frequency distribution of the equivalent diameter in the pre-strained as-built and stress-relieved samples showed that pores became bigger with strain (Figure 8). Notably in the asbuilt specimen, pore growth is already clearly visible after 1.57 per cent strain, while in the stressrelieved specimen, some growth was observed in the 9.44 per cent strained specimen. This behaviour could be associated with residual stresses in the as-built specimens. 


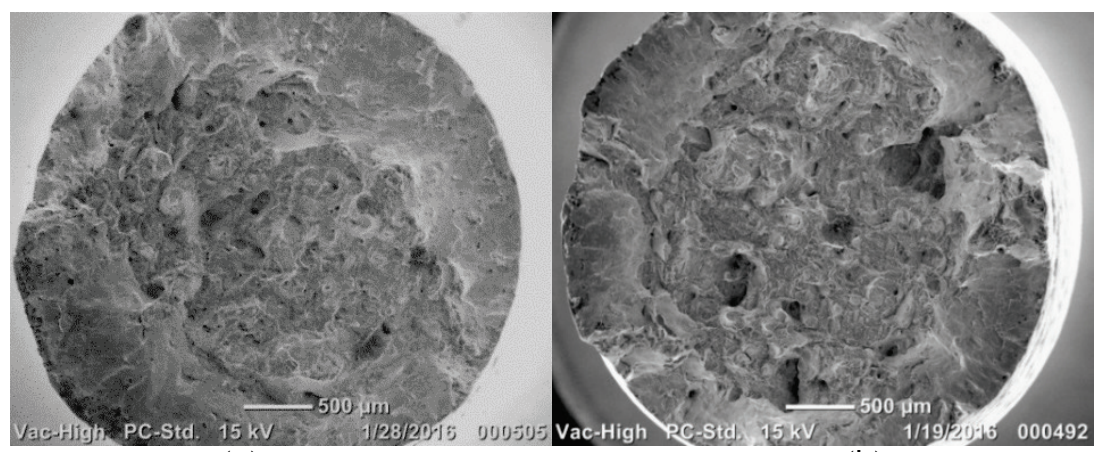

(a)

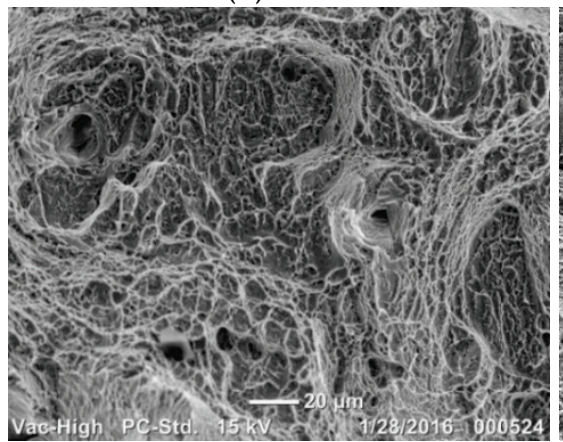

(c)

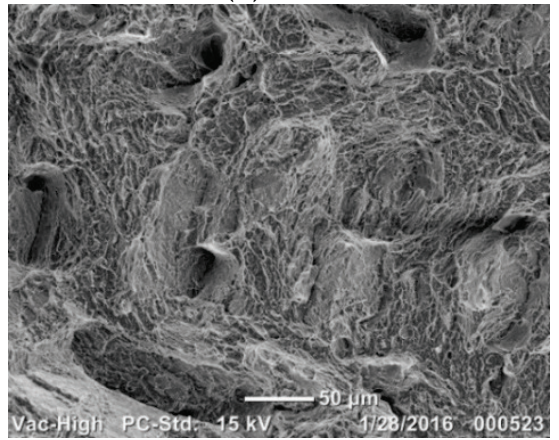

(e) (b)

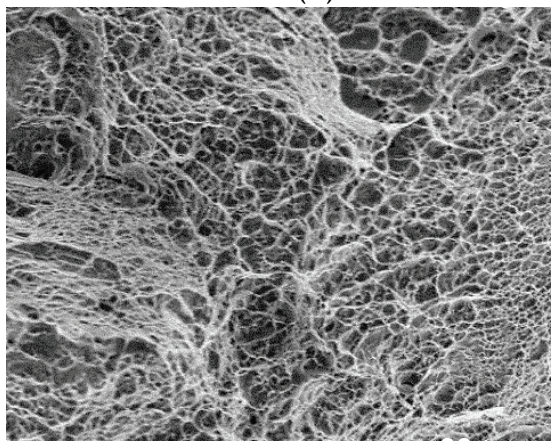

(d)

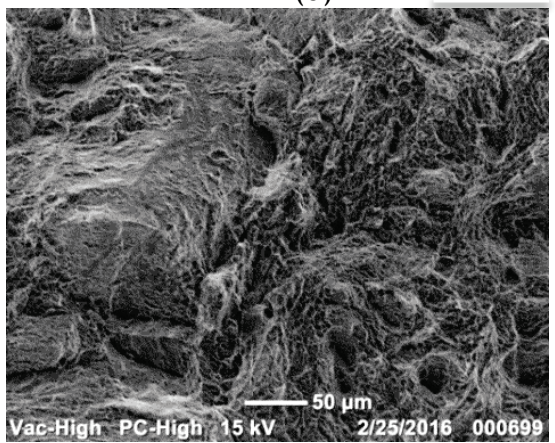

(f)

Figure 5: $(a, b)$ Fracture surface cup-and-cone, $(c, d)$ dimples, and $(e, f)$ quasi-cleavage facets in as-built (a, c, e) and stress-relieved (b, d, f) samples

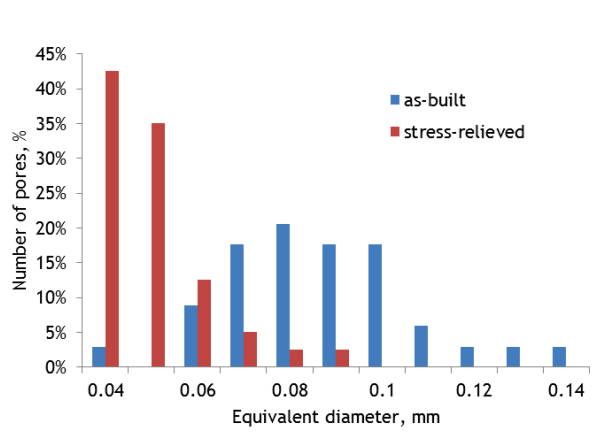

(a)

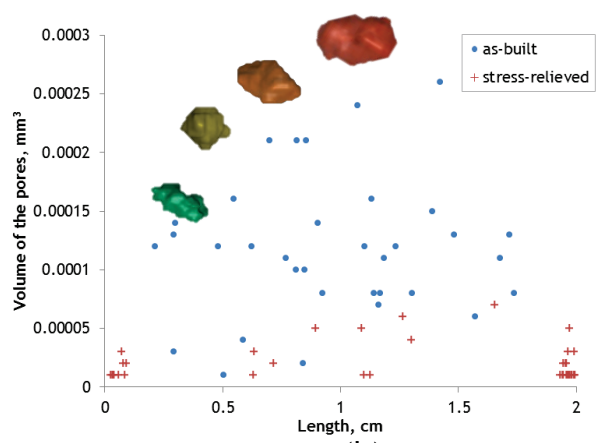

(b)

Figure 6: (a) Histogram of frequency distribution, and (b) volume of the pores with reconstruction of the biggest pores 


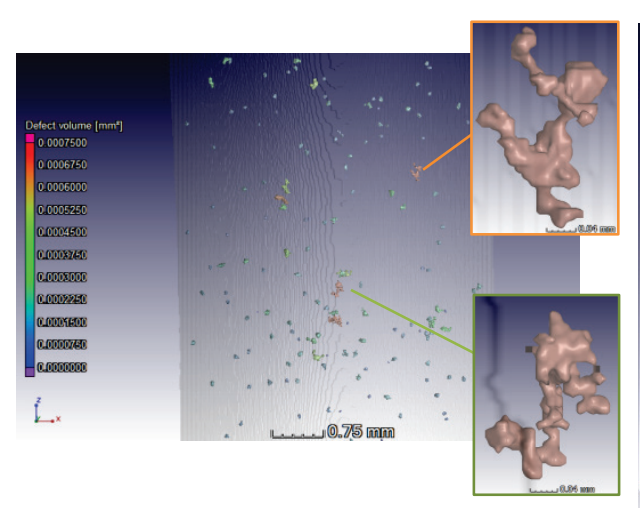

(a)

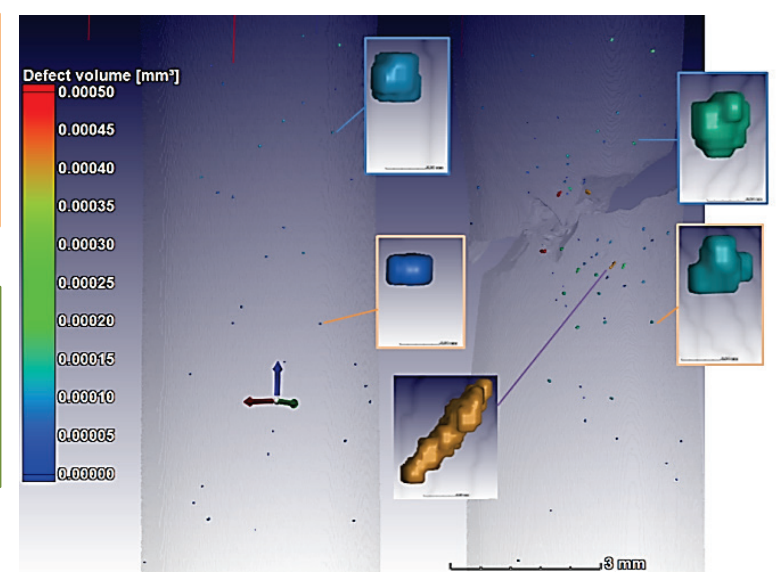

(b)

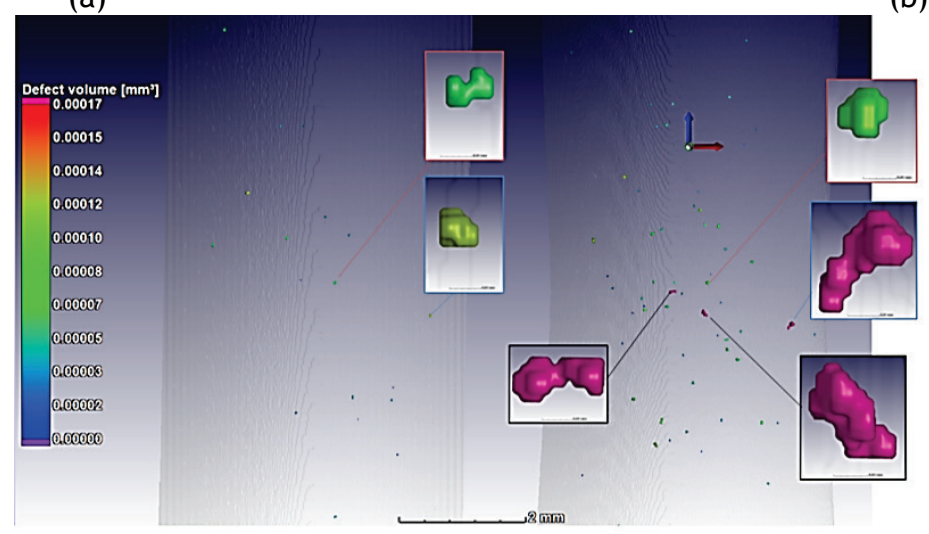

(c)

Figure 7: (a) Morphology of the pores in 8.2 per cent pre-strain as-built sample AB3; (b) the evolution of the pores in AB2; and (c) stress-relieved SR2 pre-strained samples

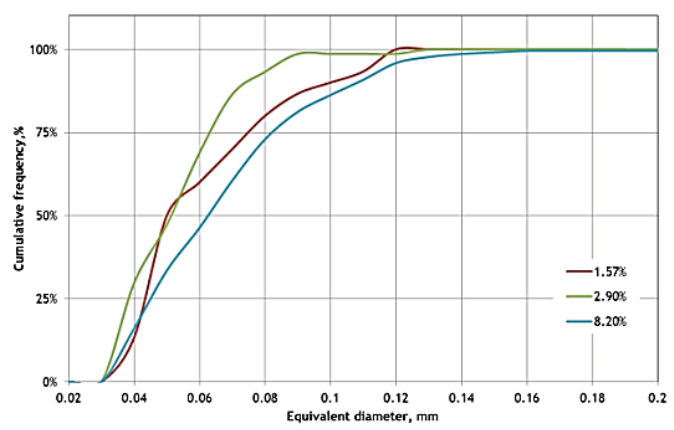

(a)

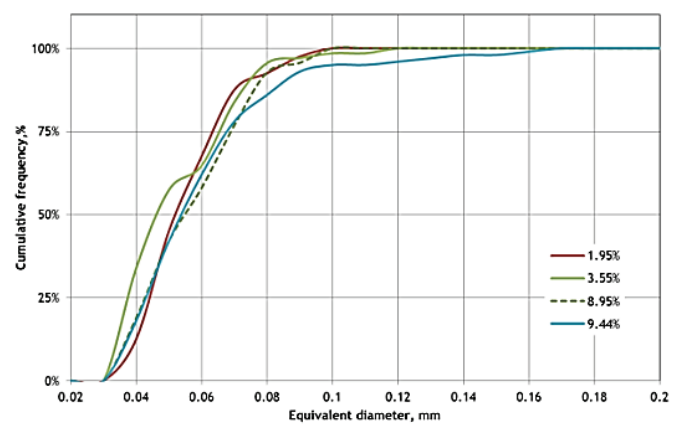

(b)

Figure 8: (a) Cumulative frequency distribution of pore sizes in pre-strained as-built and (b) stress-relieved samples. Size of the pore was calculated as the equivalent diameter of the circumscribed sphere

After DMLS, the residual stresses are large enough and are not distributed homogeneously in the sample [22]. Generally, in the final as-built samples, the residual stress distribution is complex and stresses are high. It was shown that near the surface, the Ti6Al4V (ELI) samples produced in similar conditions and attached to the substrate had tensile stresses [23]. Subsequent cutting and machining of the rectangular blocks to the shape suitable for the mechanical test also modifies the stresses. Therefore, it is difficult to conclude exactly what the stress conditions were in the interior of the tensile specimens. Nevertheless, it is clear that the superposition of stresses around a pore might result in a stress concentration above critical values, resulting in quicker pore growth. 


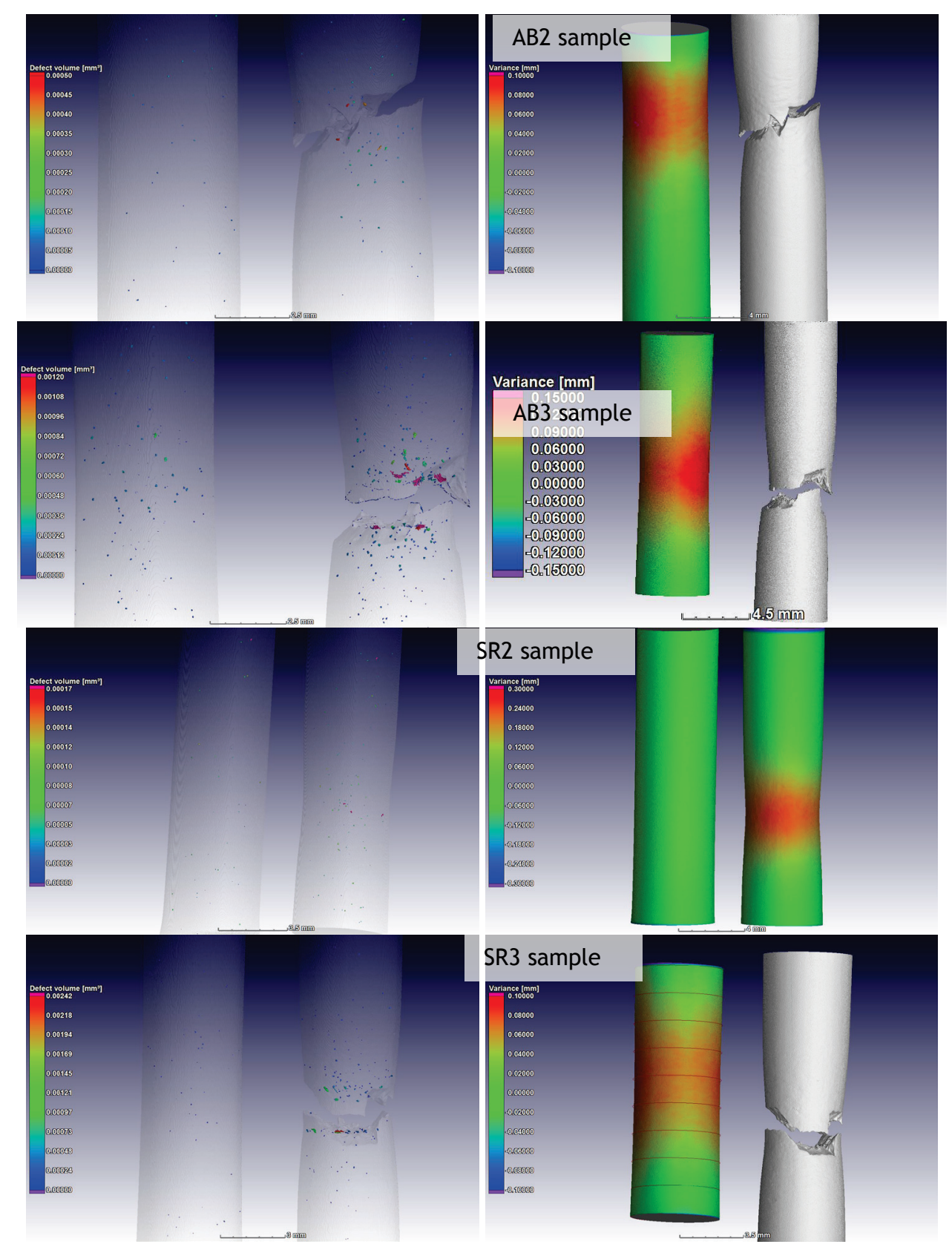

Figure 9: Coalescence of the pores and necking creation in as-built and stress-relieved samples

An analysis of porosity in the necking area in specimens strained to failure showed a much larger number of pores, small and coarse, around the crack (Figure 9).

The $A B 3$ sample, pre-strained up to 8.2 per cent, had the biggest pore size of $236 \mu \mathrm{m}$. But the fracture line in the as-built and stress-relieved samples did not cross the biggest pores when the samples were broken (Figures $7 \mathrm{~b} \&$ 9). Thus localisation of plastic deformation at tension intensifies both pore growth and pore coalescence processes. From the previous discussion, one can conclude that, if porosity is higher and pores are coarser in the as-built specimen, then the pores grow and coalesce more easily. This results in the faster formation of cracks and ultimately failure. Therefore, both the initial porosity and residual stresses resulted in a lower ductility in the as-built Ti6Al4V. Stress-relief results in the reduction of residual stresses and some changes in the microstructure, which caused an increase in elongation from 9.4 to 10.9 per cent and an area reduction from 25.6 to 29.3 per cent after heat treatment. 
In contrast with the published data, after the stress-relief of Ti6Al4V (ELI) at $650^{\circ} \mathrm{C}$ for three hours in argon atmosphere, no beta phase was detected by TEM, EBSD, and XRD. This heat treatment slightly influenced the microstructure: very small $(500 \mathrm{~nm})$ globular grains of alpha phase were found. It has been assumed that while manufacturing with different process-parameters, final structures are subjected to different conditions of in-situ cycling reheating, which influences the microstructure of the material.

Defect analysis by MicroCT showed that the DMLS Ti6A4V (ELI) samples had a high density (>99.9\%). The CT scans suggested the moderately ductile fracture mechanism of the DMLS samples under tension with formation of the necking region, which was associated with pore coarsening and coalescence.

The results of this study clearly show that if the DMLS process parameters are properly selected, the properties of DMLS specimens from Ti6Al4V (ELI) fully meet the requirements of the standards, and the only post-processing that is required is stress-relieving.

The impact of process parameters on the microstructure and mechanical properties remains an open and relevant matter for future research.

\section{ACKNOWLEDGEMENTS}

This work is based on research supported by the South African Research Chairs Initiative of the Department of Science and Technology and the National Research Foundation of South Africa (Grant №97994) and the Collaborative Programme in Additive Manufacturing (Contract №CSIR-NLC-CPAM15-MOA-CUT-01). Mechanical testing was performed in a mechanical testing laboratory at the CSIR, and the authors are grateful to Chris MCDuling. The authors also thank CRPM for manufacturing the DMLS samples.

\section{REFERENCES}

[1] De Viteri, V.S. and Fuentes, E. 2013. Titanium and titanium alloys as biomaterials. In: Gegner, J. (ed.) Tribology - Fundamentals and advancements. InTech, pp. 155-181.

[2] Donachie, M.J. 2000. Titanium: A technical guide. $2^{\text {nd }}$ edition, Materials Park, Ohio: ASM International.

[3] Boyer, R., Welsch, G. and Collings, E. 1994. Materials properties handbook: Titanium alloys. Materials Park, Ohio: ASM International.

[4] Kasperovich, G. and Hausmann, J. 2015. Improvement of fatigue resistance and ductility of TiAl6V4 processed by selective laser melting. Journal of Materials Processing Technology, 220, pp. 202-214.

[5] Xu, W., Brandt, M., Sun, S., Elambasseril, J., Liu, Q., Latham, K., Xia, K. and Qian M. 2015. Additive manufacturing of strong and ductile Ti-6Al-4V by selective laser melting via in situ martensite decomposition. Acta Materialia, 85, pp. 74-84.

[6] Vrancken, B., Thijs, L., Kruth, J.P. and Van Humbeeck, J. 2012. Heat treatment of Ti6Al4V produced by selective laser melting: Microstructure and mechanical properties. Journal of Alloys and Compounds, 541, pp. 177-185.

[7] Vilaro, T., Colin, C. and Bartout, J.D. 2011. As-fabricated and heat-treated micro-structures of the Ti-6Al$4 \mathrm{~V}$ alloy processed by selective laser melting, Metallurgical and Materials Transactions A. 42(10), pp. 31903199.

[8] Becker, T.H., Beck, M. and Scheffer, C. 2015. Microstructure and mechanical properties of direct metal laser sintered Ti-6Al-4V. South African Journal of Industrial Engineering, 26(1), pp. 1-10.

[9] Mertens, A., Reginster, S., Paydas, H., Contrepois, Q., Dormal, T., Lemaire, O. and Lecomte-Beckers, J. 2014. Mechanical properties of alloy Ti-6Al-4V and of stainless steel 316 L processed by selective laser melting: Influence of out-of-equilibrium microstructures. Powder Metallurgy, 57(3), pp. 184-189.

[10] Facchini, L., Magalini, E., Robotti, P., Molinari, A., Hoges, S. and Wissenbach, K. 2010. Ductility of a Ti6Al-4V alloy produced by selective laser melting of prealloyed powders. Rapid Prototyping Journal, 16(6), pp. 450-459.

[11] Frey, M., Shellabear, M. and Thorsson, L. 2009. Mechanical testing of DMLS parts. EOS whitepaper, EOS $\mathrm{GmbH}$, Munich.

[12] Rafi, H., Karthik, N.V., Gong, H., Starr, T.L. and Stucker, B.E. 2013. Microstructures and mechanical properties of Ti6Al4V parts fabricated by selective laser melting and electron beam melting. Journal of Materials Engineering and Performance, 22(12), pp. 3872-3883. 
[13] Murr, L.E., Quinones, S.A., Gaytan, S.M., Lopez, M.I., Rodela, A., Martinez, E.Y., Hernandez, D.H., Martinez, E., Medina, F. and Wicker, R.B. 2009. Microstructure and mechanical behavior of Ti-6Al-4V produced by rapid-layer manufacturing, for biomedical applications. Journal of the Mechanical Behavior of Biomedical Materials, 2(1), pp. 20-32.

[14] Du Plessis, A., Seifert, T., Booysen, G. and Els, J. 2014. Microfocus X-ray computed tomography (CT) analysis of laser sintered parts. South African Journal of Industrial Engineering, 25(1), pp. 39-49.

[15] Antonysamy, A.A., Prangnell, P.B. and Meyer, J. 2012. Effect of wall thickness transitions on texture and grain structure in additive layer manufacture (ALM) of Ti6Al4V. Materials Science Forum, 706-709, pp. 205210.

[16] Simonelli, M., Tse, Y.Y. and Tuck, C. 2014. On the texture formation of selective laser melted Ti-6Al-4V. Metallurgical and Materials Transactions A, 45(6), pp. 2863-2872.

[17] Sallica-Leva, E., Caram, R., Jardini, A.L. and Fogagnolo, J.B. 2016. Ductility improvement due to martensite $a^{\prime}$ decomposition in porous Ti-6Al-4V parts produced by selective laser melting for orthopedic implants. Journal of the Mechanical Behavior of Biomedical Materials, 54, pp. 149-158.

[18] Simonelli, M., Tse, Y.Y. and Tuck, C. 2014a. Effect of the build orientation on the mechanical properties and fracture modes of SLM Ti-6Al-4V. Materials Science and Engineering: A, 616, pp. 1-11.

[19] Simonelli, M., Tse, Y.Y. and Tuck, C. 2014b. The formation of alpha plus beta microstructure in asfabricated selective laser melting of Ti-6Al-4V. Journal of Materials Research, 29(17), pp. 2028-2035.

[20] Wen, S., Li, S., Wei, Q., Yan, C., Zhang, S. and Shi, Y. 2014. Effect of molten pool boundaries on the mechanical properties of selective laser melting parts. Journal of Materials Processing Technology, 214, pp. 2660-2667.

[21] Du Plessis, A. and Rossouw, P. 2015. Investigation of porosity changes in cast Ti6Al4V rods after hot isostatic pressing. Journal of Materials Engineering and Performance, 24(8), pp. 3137-3141.

[22] Yadroitsev, I. and Yadroitsava, I. 2015. Evaluation of residual stress in stainless steel 316L and Ti6Al4V samples produced by selective laser melting. Virtual and Physical Prototyping, 10(2), pp. 67-76.

[23] Yadroitsava I., Grewar S., Hattingh D. and Yadroitsev I. 2015. Residual stress in SLM Ti6Al4V alloy specimens. Materials Science Forum, 828-829, pp. 305-310. 